Tomasz Dubowski

\title{
CZYNNIK CZASU W FUNKCJONOWANIU MIĘDZYNARODOWYCH TRYBUNAŁÓW KARNYCH - WYBRANE ASPEKTY
}

\section{Wprowadzenie}

Działalność współczesnych międzynarodowych trybunałów karnych wiąże się bezpośrednio z niezwykle ważnym i ciekawym zagadnieniem odpowiedzialności jednostki w prawie międzynarodowym. Natężenie przestępczości wykraczającej poza granice poszczególnych państw przypada na wiek XIX i wiązane jest często z ówczesnym intensywnym rozwojem nauki i techniki ${ }^{1}$. Idee utworzenia organów egzekwujących odpowiedzialność jednostki za naruszenie prawa międzynarodowego wydają się jednak przede wszystkim naturalną konsekwencją ilości, skali i formy naruszeń prawa podczas licznych konfliktów zbrojnych w XIX i XX wieku. Autorzy podręcznika „Podstawy prawa karnego międzynarodowego” przytaczają słowa manifestu cesarza pruskiego Wilhelma II do korpusu żołnierzy wysyłanych do Chin: (...) nie dawać pardonu, nie brać jeńców. Ktokolwiek wpadnie w wasze ręce musi zginąć. Tak jak tysiąc lat temu Hunowie pod wodzą Attyli zyskali sobie straszną sławę (...) uczyńcie imię Niemców tak sławnym w Chinach, by przez tysiąc lat żaden Chińczyk nie odważył się spojrzeć spode łba na Niemca"2. Mimo upływu dekad, okrucieństwo jest stałym elementem konfrontacji militarnych, których doświadczała Europa oraz pozostałe kontynenty. Reakcją społeczności międzynarodowej na ten stan rzeczy stało się dążenie do ustanowienia organów zdolnych do osądzania osób odpowiedzialnych za czyny stanowiące naruszenie prawa międzynarodowego ${ }^{3}$. Funkcjonowanie międzynarodowych trybunałów karnych okazało się swego rodzaju koniecznością.

\footnotetext{
$1 \quad$ I. Gawłowicz, M.A. Wasilewska, Międzynarodowa współpraca w walce z przestępczością (międzynarodowe trybunały karne, Interpol), Szczecin 2004, s. 31-32.

Tak zwana „mowa huńska” cesarza Wilhelma II wygłoszona do żołnierzy wysłanych do Chin w 1900 roku w związku z „powstaniem bokserów”. Cyt. za: M. Królikowski, P. Wiliński, J. Izydorczyk, Podstawy prawa karnego międzynarodowego, Warszawa 2008, s. 52. nowiących zbrodnie prawa międzynarodowego i podlegających powszechnej jurysdykcji. Problem ten wykra-
} 
Ukształtowany obecnie system sądownictwa międzynarodowego w aspekcie odpowiedzialności jednostki za naruszenie prawa międzynarodowego jest systemem obejmującym organy o niejednolitym charakterze, różnych funkcjach i kompetencjach. Nie sposób jednak nie zauważyć, iż okoliczności ich powstania oraz pewne ich cechy można poddać analizie z perspektywy czynnika czasu. „Element czasu" posiada bowiem istotne znaczenie - zarówno w odniesieniu do genezy, typologii ,jak i zakresu jurysdykcji funkcjonujących obecnie międzynarodowych trybunałów karnych. Zagadnienia te zostaną zbadane w niniejszym opracowaniu. Jednocześnie, $\mathrm{z}$ racji na przyjęte założenia redakcyjne, poniższe rozważania koncentrować się będą w głównej mierze wokół działalności trybunałów międzynarodowych ad hoc utworzonych przez ONZ oraz Międzynarodowego Trybunału Karnego ${ }^{4}$.

\section{Trybunały ad hoc i Międzynarodowy Trybunał Karny}

Zbadanie wybranych zagadnień związanych z funkcjonowaniem współczesnych trybunałów karnych przez pryzmat czynnika czasu wymaga uprzedniego zwięzłego opisu organów międzynarodowych poddanych analizie.

Pod pojęciem międzynarodowych trybunałów karnych ad hoc rozumiane będą: Międzynarodowy Trybunał Karny dla byłej Jugosławii (dalej MTKJ) oraz Międzynarodowy Trybunał Karny dla Ruandy (dalej MTKR). Oba trybunały utworzone zostały na mocy rezolucji Rady Bezpieczeństwa ONZ ${ }^{5}$ i już sam sposób ich utworzenia wzbudził szereg kontrowersji ${ }^{6}$. Podstawą powołania obu trybunałów stały się przepisy Rozdziału VII Karty Narodów Zjednoczonych, ${ }^{7}$ upoważniające Radę Bezpieczeństwa do podejmowania działań na rzecz utrzymania międzynarodowego pokoju i bezpieczeństwa. W podobny sposób ukształtowano strukturę obu trybunałów oraz zakres ich jurysdykcji ratione personae - należy podkreślić, iż MTKJ i MTKR posiadają jurysdykcję wyłącznie w odniesieniu do osób fizycznych. W zbliżony sposób uregulowano kompetencje ratione materiae obu trybunałów - różnice w tej materii wiążą się z uznaniem konfliktu w Ruandzie za konflikt nieposiadający cha-

cza jednak poza ramy niniejszego opracowania. Więcej na ten temat zob. m.in. M. Zdanowicz, T. Dubowski, The Liability of an Individual in Modern International Law, "Studies in Logic, Grammar and Rhetoric" 2007, nr 12(25) s. 134-140.

4 Dalsze analizy nie będą zatem obejmować zagadnień związanych z funkcjonowaniem tzw. quasi-trybunałów czy trybunałów hybrydowych o mieszanym składzie i jurysdykcji.

5 Zob. odpowiednio: Resolution 827 (1993), Adopted by the Security Council at its 3217th meeting, on 25 May 1993 oraz Resolution 955 (1994), Adopted by the Security Council at its 3453th meeting, on 8 November 1994, źródło: http://www.un.org/Docs/scres/1993/scres93.htm [data weryfikacji: 27 kwietnia 2010 r.].

6 Por. m.in.: T. Dubowski, Działania (akty) »ultra vires« w świetle odpowiedzialności organizacji międzynarodowych - wybrane zagadnienia, (w:) A. Kozłowski, B. Mielnik (red.), Odpowiedzialność międzynarodowa jako element międzynarodowego porządku prawnego, Wrocław 2009, s. 325-328.

7 Karta Narodów Zjednoczonych, (w:) A. Łazowski, Prawo międzynarodowe publiczne, Kraków 2003. 
rakteru międzynarodowego ${ }^{8}$. MTKJ posiada jurysdykcję w zakresie poważnych naruszeń Konwencji Genewskich z 1949 r., ludobójstwa, zbrodni przeciwko ludzkości oraz naruszeń praw i zwyczajów wojennych. MTKR tymczasem posiada jurysdykcję w odniesieniu do naruszeń art. 3 wspólnego dla Konwencji Genewskich, zbrodni przeciwko ludzkości oraz ludobójstwa.

Jurysdykcja ratione loci trybunałów różni się w sposób naturalny. Jurysdykcja MTKJ rozciaga się na terytorium byłej Federacyjnej Republiki Jugosławii, podczas gdy jurysdykcja MTKR na terytorium lądowe i przestrzeń powietrzną Ruandy oraz terytoria państw ościennych, w wypadku zbrodni popełnionych przez obywateli Ruandy.

Różny jest także zakres jurysdykcji ratione temporis obu trybunałów. Problemowi temu poświęcony zostanie odrębny punkt opracowania. W tym miejscu warto jednak zasygnalizować, iż sposób ukształtowania jurysdykcji czasowej MTKJ i MTKR przemawia za uznaniem ich charakteru jako trybunałów ad hoc, tj. organów pozbawionych przymiotu stałości, a powołanych przez społeczność międzynarodową do osądzenia zbrodni popełnionych w trakcie konkretnego konfliktu?

Międzynarodowy Trybunał Karny (dalej MTK) jest natomiast organem o charakterze stałym. Powstał na mocy podpisanego w dn. 17 lipca 1998 roku Statutu Rzymskiego MTK ${ }^{10}$, który wszedł w życie 1 lipca 2002 roku. Jego siedzibą jest Haga. Jurysdykcja ratione materiae obejmuje najpoważniejsze pogwałcenia prawa międzynarodowego: zbrodnię ludobójstwa, zbrodnie przeciwko ludzkości, zbrodnie wojenne oraz zbrodnię agresji. Jurysdykcja MTK w wymiarze podmiotowym rozciąga się na osoby fizyczne, zaś w aspekcie czasowym na zbrodnie popełnione po wejściu w życie Statutu MTK oraz po wejściu w życie Statutu w stosunku do państwa, które stało się jego stroną po 1 lipca 2002 roku.

Ważną cechą MTK jest fakt, iż jego jurysdykcja posiada charakter komplementarny względem jurysdykcji organów krajowych. Oznacza to, iż MTK swą jurysdykcję wykonuje dopiero wówczas, gdy właściwe organy państwowe nie przejawiają woli lub nie są w stanie ścigać i karać osób winnych popełnienia wskazanych wyżej zbrodni.

Powyższa - siłą rzeczy skrótowa - charakterystyka współczesnych międzynarodowych trybunałów karnych wydaje się odpowiednim wstępem do dalszych rozważań poświęconych wprost czynnikowi czasu w ich funkcjonowaniu. narodowe, Wrocław 2009, s. 209-210.

$9 \quad$ M. Królikowski, P. Wiliński, J. Izydorczyk, op. cit., s. 50-51.

10 RomeStatute of the International Criminal Court, źródło: http://www.icc-cpi.int/Menus/lCC/Legal+Texts+and+Tools/ Official+Journal/Rome+Statute.htm [data weryfikacji: 24 kwietnia 2010 r.]. 


\section{Czynnik czasu a rozwój współczesnego międzynarodowego sądownictwa karnego}

Doświadczenia konfliktów zbrojnych drugiej połowy XIX wieku, obu wojen światowych oraz kolejnych konfliktów o mniejszym zasięgu w XX wieku mogłyby przemawiać za natychmiastowym utworzeniem odpowiednich warunków prawnych $\mathrm{i}$ instytucjonalnych $\mathrm{w}$ zakresie odpowiedzialności jednostki za naruszenie prawa międzynarodowego ${ }^{11}$. Idea utworzenia stałego sądu właściwego w zakresie osądzania najpoważniejszych naruszeń prawa międzynarodowego pojawiła się jeszcze w drugiej połowie XIX wieku ${ }^{12}$. Realizacja celu, jakim stało się stosunkowo pełne i klarowne uregulowanie założeń odpowiedzialności sprawców przestępstw międzynarodowych, nastąpiła jednak dopiero wraz z ustanowieniem Międzynarodowego Trybunału Karnego ${ }^{13}$ jako organu sądowniczego o charakterze stałym, co miało miejsce w 1998 roku. Powstanie MTK można zatem traktować jako uwieńczenie długotrwałego procesu kształtowania się stałego sądownictwa karnego w wymiarze międzynarodowoprawnym.

Jeżeli za pierwszą próbę pociągnięcia jednostki do odpowiedzialności za określone kategorie zbrodni przed organem międzynarodowym uznać postawienie przed trybunałem międzynarodowym cesarza Wilhelma II Hohenzollerna w 1919 r., wypada podkreślić, iż od tego momentu do utworzenia współczesnych trybunałów karnych ad hoc minęło ponad siedemdziesiąt lat, zaś do ustanowienia trybunału o charakterze stałym (MTK) - prawie osiemdziesiąt. Jest to zatem okres relatywnie długi. Pojawia się jednak pytanie, czy ów - tak długi - czas okazał się okresem rzeczywiście koniecznym dla powstania współczesnych trybunałów karnych w określonym kształcie, czy też raczej długotrwałość sygnalizowanych procesów była pochodną niefrasobliwości społeczności międzynarodowej, przejawem lekceważenia problemów niezwykle istotnych. Warto jednak na tym tle poczynić pewne uwagi.

Proces kształtowania się norm i instytucji prawa międzynarodowego publicznego jest procesem z natury rzeczy stosunkowo długotrwałym. Wiąże się to ze specyfiką prawa międzynarodowego, którego normy tworzone są przez jego podmioty, czyli głównie państwa. Jednocześnie podstawą obowiązywania określonej normy prawa międzynarodowego w stosunku do danego państwa jest jego zgoda wyrażona w odpowiedniej formie ${ }^{14}$. Kształtowanie się zgodnej woli państw w odniesieniu do

11 W odniesieniu do odpowiedzialności międzynarodowoprawnej jednostek owe naruszenia obejmuja zasadniczo kategorię tzw. zbrodni międzynarodowych (zbrodnie przeciw ludzkości, ludobójstwo, zbrodnie wojenne, zbrodnie przeciwko pokojowi), wiążących się z indywidualną odpowiedzialnością sprawcy. Por. M. Rogacka-Rzewnicka, Prawo międzynarodowe karne: rozwój i perspektywy sądownictwa międzynarodowego w sprawach karnych, „Studia luridica” 2003, t. 41, s. 222-223.

12 M. Królikowski, P. Wiliński, J. Izydorczyk, ibidem.

13 M. Rogacka-Rzewnicka, op. cit., s. 216.

14 W. Góralczyk, S. Sawicki, Prawo międzynarodowe publiczne w zarysie, Warszawa 2004, s. 22-23. 
konkretnych norm może - w zależności od warunków i okoliczności - przebiegać wieloetapowo na przestrzeni szeregu lat. Zauważmy, iż elementem kluczowym powstania normy prawa zwyczajowego jest „długotrwała” praktyka (oraz towarzyszące jej przekonanie o jej prawotwórczym charakterze). Formułowanie zgodnej woli państw w odniesieniu do norm traktatowych również może być procesem długotrwałym - zarówno w bezpośrednich relacjach międzypaństwowych, jak i na forum organizacji międzynarodowych. Pozostając w obszarze odpowiedzialności międzynarodowej, warto wskazać problem odpowiedzialności organizacji międzynarodowych. Prace nad konwencją regulującą tę kwestię toczą się w zasadzie od początku XXI wieku (2000 rok). Projekt konwencji ${ }^{15}$ przedstawiono w roku 2009 i już dziś wiadomo, iż kolejne kroki na drodze do jej przyjęcia podjęte zostaną dopiero w $2011 \mathrm{r}$.

Tym samym w obu przypadkach - prawa traktatowego i zwyczajowego - element czasu staje się niezwykle ważnym czynnikiem kształtowania się zbiorowej woli państw. Ta z kolei pozostaje niezbędnym warunkiem skutecznej realizacji określonej idei o wymiarze międzynarodowym ${ }^{16}$. Jak zauważa M. Rogacka-Rzewnicka, jest to szczególnie istotne w wypadku idei uosabiających pewne „fundamentalne wartości współczesnego świata, międzynarodową praworządność czy też uniwersalną sprawiedliwość" ${ }^{17}$. Ideą taką stało się bez wątpienia utworzenie międzynarodowego trybunału zdolnego egzekwować odpowiedzialność jednostki za określone kategorie zbrodni. Jej rozwój odbywał się przy tym w specyficznych warunkach.

Warto bowiem pamiętać, iż odpowiedzialność jednostki za zbrodnie prawa międzynarodowego może być egzekwowana także w ramach krajowych porządków prawnych. W tym świetle długotrwały charakter procesu kształtowania się współczesnych trybunałów karnych staje się zrozumiały. Państwa nie są skłonne do przekazywania własnej jurysdykcji karnej organom międzynarodowym, dostrzegając w tym ograniczenie suwerenności ${ }^{18}$. Karanie sprawców przestępstw międzynarodowych wolą utrzymać w zakresie własnych kompetencji, co jest oczywiście możliwe na podstawie odpowiednich krajowych przepisów karnych ${ }^{19}$. Warto także dodać, iż okres powojenny charakteryzowały szczególne okoliczności polityczne wywierające znaczący wpływ na możliwości efektywnej współpracy międzynarodowej²0 to 7 August 2009), źródło: http://untreaty.un.org/ilc/reports/2009/2009report.htm [data weryfikacji: 24 kwietnia 2010 r.].

16 M. Rogacka-Rzewnicka, op. cit, s. 215.

17 Ibidem

18 K. Karski, Realizacja idei utworzenia międzynarodowego sądownictwa karnego, „Państwo i Prawo” 1993, z. 7, s. 65.

19 M. Rogacka-Rzewnicka, ibidem.

20 I. Gawłowicz, M.A. Wasilewska, op. cit., s. 142. 
Mimo powyższych trudności, czas jaki upłynął między pierwszymi próbami ustanowienia organów międzynarodowych zdolnych do efektywnego osądzania jednostek za określone zbrodnie prawa międzynarodowego a utworzeniem trybunałów karnych w aktualnym kształcie, stał się czasem poważnego rozwoju koncepcji i regulacji prawnych rzutujących na stan obecny. Zauważmy m.in., iż działalność międzynarodowych trybunałów wojskowych (Międzynarodowy Trybunał Wojskowy w Norymberdze oraz Międzynarodowy Trybunał Wojskowy dla Dalekiego Wschodu z siedzibą w Tokio) wywarła znaczący wpływ na kształtowanie zasad ponoszenia odpowiedzialności prawnomiędzynarodowej przez jednostki. Szczególnie istotny wydaje się w tej mierze dorobek Trybunału Norymberskiego - jakkolwiek sam trybunał nie miał charakteru stałego, wypracowane w toku jego działalności reguły i zasady odpowiedzialności jednostki oraz funkcjonowania trybunału okazały się ów walor trwałości posiadać. Jako tzw. „Zasady Norymberskie” doczekały się stosunkowo szybko kodyfikacji - w formie listy opracowanej przez Komisję Prawa Międzynarodowego przedstawione zostały jako zasady prawa międzynarodowego i jako takie potwierdzone rezolucją Zgromadzenia Ogólnego NZ nr 488 z dnia 12 grudnia 1950 roku. Zasady te określały m.in. kategorie zbrodni prawa międzynarodowego, warunki odpowiedzialności międzynarodowej jednostki oraz zakres ochrony jednostki sądzonej za popełnienie jednej ze zbrodni prawa międzynarodowego. Zasady te są powszechnie akceptowane również dziś, a ich wpływ na kształt i funkcjonowanie współczesnych trybunałów karnych jest bezsporny.

Sformułowanie „Zasad Norymberskich” nie pozostało jedynym efektem działalności międzynarodowych trybunałów wojskowych. Ich funkcjonowanie można do pewnego stopnia postrzegać jako impuls wiodący społeczność międzynarodową do kolejnych prób powołania stałego trybunału międzynarodowego o charakterze stałym i uniwersalnej jurysdykcji. Projekty ustanowienia międzynarodowego kodeksu karnego oraz Międzynarodowego Trybunału Karnego z drugiej połowy lat czterdziestych XX wieku - jakkolwiek nieudane - są tego dowodem. Mimo iż doświadczenia obu wojen światowych nie doprowadziły do ustanowienia stałego międzynarodowego sądownictwa karnego, w okresie powojennym podjęto jednak skutecznie wiele inicjatyw na rzecz rozwoju prawa międzynarodowego w zakresie odpowiedzialności jednostki za zbrodnie międzynarodowe. Inicjatywy te przyniosły efekt w postaci tak znaczących aktów prawa międzynarodowego, jak m.in. Konwencja w sprawie zapobiegania i karania zbrodni ludobójstwa (1948 r.), III Konwencja Genewska (1949 r.) oraz Konwencja Tokijska, Haska i Montrealska w zakresie prawa lotniczego czy Konwencja Narodów Zjednoczonych o prawie morza (1982 r.) - w zakresie, w jakim odnoszą się do odpowiedzialności jednostki.

Oczywiście, z punktu widzenia rozwoju międzynarodowego sądownictwa karnego wskazany dorobek prawny może wydawać się zbiorem regulacji o znaczeniu marginalnym - między innymi z tego powodu, iż co do zasady przewidują one, iż 
jednostka jest sądzona przed sądami krajowymi ${ }^{21}$. Z drugiej jednak strony nie sposób nie zauważyć, iż wskazane regulacje stanowią przejaw kształtowania się wspólnej woli państw ścigania i karania sprawców przestępstw międzynarodowych. Zgodnie zaś z wcześniejszymi uwagami jest to niezwykle ważny element procesów prowadzących do powstania dzisiejszych trybunałów ad hoc oraz MTK. Wydarzenia z początku lat dziewięćdziesiątych w Somalii, byłej Jugosławii oraz w Ruandzie okazały się dla społeczności międzynarodowej wyzwaniem, któremu nie można było sprostać bez intensyfikacji prac nad stworzeniem organów międzynarodowych upoważnionych do osądzania jednostek za określone zbrodnie. W efekcie, w latach 1993-1994 doszło do powstania trybunałów ad hoc - Międzynarodowego Trybunału Karnego dla byłej Jugosławii oraz Międzynarodowego Trybunału Karnego dla Ruandy ${ }^{22}$. Ich funkcjonowanie jest $\mathrm{z}$ kolei postrzegane jako bezpośredni impuls na drodze do ustanowienia stałego sądu międzynarodowego - MTK.

Podsumowując, wypada podkreślić wagę czynnika czasu w rozwoju funkcjonujących obecnie międzynarodowych trybunałów karnych. Czas, który okazał się niezbędny do ich ustanowienia, jest okresem szeregu prób rozwoju prawnych i instytucjonalnych form egzekwowania odpowiedzialności jednostki w prawie międzynarodowym. Te z kolei wpłynęły nie tylko na treść aktualnych rozwiązań prawnych w omawianym zakresie, lecz także przyczyniły się do rozwoju prawa międzynarodowego publicznego w tak ważkim aspekcie, jak szeroko rozumiany problem podmiotowości międzynarodowej jednostki. Jednocześnie długotrwałość procesów prowadzących do ustanowienia MTKJ i MTKR oraz Międzynarodowego Trybunału Karnego wydaje się być konsekwencją określonej sytuacji politycznej, a także, do pewnego stopnia, wpisuje się w specyfikę samego prawa międzynarodowego publicznego.

\section{Czynnik czasu a typologia międzynarodowych trybunałów karnych}

Międzynarodowe trybunały karne, jak sygnalizowano wyżej, nie stanowią jednolitej grupy organów. Elementami różnicującymi poszczególne formy organów sądowych w omawianym kontekście są m.in.: ich status prawny, sposób powołania czy zakres pełnionych funkcji ${ }^{23}$. W literaturze prawa karnego międzynarodowego proponuje się typologię międzynarodowych trybunałów karnych, która wyodrębnia tzw. trybunały in statu creandi, trybunały wojskowe o charakterze doraźnym, trybunały ad hoc, trybunały stałe oraz tzw. trybunały o charakterze mieszanym (qua-

21 M. Zdanowicz, T. Dubowski, op. cit., s. 140.

22 Należy w tym miejscu podkreślić wiodąca, aktywną rolę ONZ.

23 M. Królikowski, P. Wiliński, J. Izydorczyk, op. cit., s. 50. 
$s i$-trybunały - organy, które pozostają poza ramami niniejszego opracowania $)^{24}$. Niewątpliwie zaprezentowaną typologię można postrzegać również przez pryzmat czynnika czasu. Czynnik ów przesądza bowiem o charakterze określonego organu i jego miejscu w proponowanej klasyfikacji.

Jeżeli za trybunały in statu creandi uznamy trybunały, które powołano lub których statuty zostały uchwalone, a które nie rozpoczęły swojej działalności (m.in. wzmiankowane projekty ustanowienia Międzynarodowego Trybunału Karnego z połowy XX wieku) ${ }^{25}$, wypada zauważyć, iż dla ich funkcjonowania czas nie posiada żadnego znaczenia. Trudno zatem w tym wypadku, posługując się kryterium czasu, definiować tego rodzaju trybunały jako stałe bądź czasowe. Można chyba jednak przyjąć, iż nieudane próby ich ustanowienia wpisują się w ,czas” rozumiany jako okres kształtowania się zbiorowej, wspólnej woli państw w odniesieniu do tworzenia systemu efektywnego sądownictwa międzynarodowego w wymiarze karnym, o czym mowa była w punkcie poprzednim.

Czynnik czasu największe znaczenie wydaje się posiadać z punktu widzenia funkcjonowania trybunałów określanych jako trybunały wojskowe (doraźne), trybunały ad hoc oraz trybunały stałe.

Trybunałami doraźnymi są trybunały powoływane do sądzenia sprawców zbrodni międzynarodowych popełnionych w trakcie konfliktu zbrojnego. Co ważne, organy te ustanawiane są przez państwa zwycięskie celem ścigania i karania osób odpowiedzialnych za naruszenia prawa międzynarodowego po stronie państwa (państw) pokonanych. Przykładami takich trybunałów są oczywiście, przywoływane wcześniej, trybunał norymberski oraz tokijski. Z kolei trybunałami ad hoc sa trybunały ustanowione w celu osądzenia sprawców zbrodni popełnionych w trakcie trwania określonego konfliktu. Te trybunały powoływane są jednak nie przez same strony konfrontacji, a przez społeczność międzynarodową (np. ONZ). Do tej kategorii zaliczane są MTKJ i MTKR.

W obu powyższych wypadkach czynnik czasu determinuje charakter $\mathrm{i}$ istotę trybunałów karnych. Zauważmy, iż ich ścisłe związanie z określonym konfliktem, określoną sytuacją międzynarodową przesądza o ich istocie jako organów o charakterze nietrwałym, przejściowym. Trybunały te powołuje się celem osądzenia zbrodni międzynarodowych popełnionych w ustalonym czasie, na ustalonym obszarze i przez ustalone kategorie podmiotów. Wyklucza to uznanie ich za organy o stałym charakterze.

W przypadku trybunałów doraźnych (wojskowych) celem stało się osądzenie sprawców najcięższych naruszeń prawa międzynarodowego w trakcie II wojny 
światowej. Wraz z wykonaniem zadania trybunały kończyły swą działalność. Tym samym ramy czasowe ich działalności okazały się stosunkowo dokładnie określone. W konsekwencji czas ustalił ich naturę jako organów niestałych.

Podobnie kwestia czasu wygląda w odniesieniu do trybunałów ad hoc (MTKJ i MTKR), które, przypomnijmy, ustanowione zostały przez organ ONZ (Rada Bezpieczeństwa) w celu ścigania i karania sprawców zbrodni międzynarodowych popełnionych w trakcie konkretnego konfliktu zbrojnego w stosunkowo precyzyjnie ustalonych ramach czasowych. Ich istota jako organów czasowych wydaje się niewątpliwa. Dobrą tego ilustracją stają się regulacje rezolucji Rady Bezpieczeństwa ustanawiające MTKJ i MTKR. W wypadku Międzynarodowego Trybunału dla byłej Jugosławii rezolucja $827^{26}$ jest podstawą utworzenia międzynarodowego trybunału wytqcznie w celu osqdzenia osób odpowiedzialnych za poważne naruszenia międzynarodowego prawa humanitarnego na terytorium byłej Jugosławii między dniem 1 stycznia 1991 r. do momentu określonego przez Radę Bezpieczeństwa (do czasu przywrócenia pokoju). Rezolucja 955 ustanawiająca MTKR zawiera zbliżone sformułowania - Rada Bezpieczeństwa podejmuje decyzję w sprawie ustanowienia międzynarodowego trybunatu powołanego wyłacznie $w$ celu ścigania osób odpowiedzialnych za ludobójstwo oraz inne poważne naruszenia międzynarodowego prawa humanitarnego popetnione na terytorium Ruandy oraz obywateli Ruandy odpowiedzialnych za ludobójstwo i podobne zbrodnie popetnione na terytorium państw ościennych ${ }^{27}$. Przytoczone postanowienia obu rezolucji wyraźnie wskazują, iż przed MTKJ i MTKR postawiono konkretne zadania w związku z konfliktami umiejscowionymi w określonej przestrzeni i czasie. Realizacja tych zadań powinna - jak się wydaje - oznaczać kres działalności trybunałów.

W istocie, w miarę rozwoju działalności obu trybunałów począł kształtować się plan zakończenia ich funkcjonowania (completion strategy). W rezolucji Rady Bezpieczeństwa $1503(2003)^{28}$ znalazło się wyraźne wezwanie do podjęcia przez trybunały wszelkich koniecznych środków w celu ukończenia śledztw do 2004 r. oraz zamknięcia postępowań w pierwszej instancji do końca 2008 r., zaś wszelkich prac MTKJ i MTKR do końca 2010 r. Szacunki z roku 2009 potwierdzają jednak, iż postępowania w trybunałach zostaną zamknięte do połowy 2011 roku, z wyjątkiem sprawy R. Karadžića (druga połowa 2012 roku). Postępowania apelacyjne z kolei powinny zostać zakończone do połowy 2013 r. (ponownie z wyjątkiem sprawy Karadžića - jej zamknięcie przewiduje się na luty 2014 roku).

26 Resolution 827 (1993), Adopted by the Security Council at its 3217th meeting,
www.un.org/Docs/scres/1993/scres93.htm [data weryfikacji: 27 kwietnia 2010 r.].

27

Resolution 955 (1994), Adopted by the Security Council at its 3453th meeting, on 8 November 1994, źródło: http://www.un.org/Docs/scres/1993/scres93.htm [data weryfikacji: 27 kwietnia 2010 r.].

Resolution 1503 (2003) Adopted by the Security Council at its 4817th meeting, on 28 August 2003, źródło: http://daccess-dds-ny.un.org/doc/UNDOC/GEN/N03/481/70/PDF/N0348170.pdf?OpenElement [data weryfikacji: 26 kwietnia 2010 r.]. 
Na tym tle w odmienny sposób prezentuje się Międzynarodowy Trybunał Karny. Artykuł 1 Rzymskiego Statutu Trybunału ${ }^{29}$ stanowi, iż MTK będzie instytucją stała, wykonującą swoją jurysdykcję w stosunku do osób odpowiedzialnych za najpoważniejsze zbrodnie prawa międzynarodowego. Co więcej, Statut Rzymski wyposaża Trybunał w podmiotowość prawną (The Court shall have international legal personality - art. 4 ust. 1 Statutu). Zatem czynnik „czasu” w odniesieniu do charakteru MTK czyni zeń organ międzynarodowy o charakterze stałym - jest on stałym trybunałem międzynarodowym egzekwującym odpowiedzialność jednostek za popełnione zbrodnie.

Powyższe uwagi wskazują, iż element czasu determinuje charakter poszczególnych trybunałów międzynarodowych i przesądza o ich miejscu w proponowanych współcześnie klasyfikacjach tego rodzaju organów. W odniesieniu do MTKJ, MTKR oraz Międzynarodowego Trybunału Karnego kryterium czasu pozwala zakwalifikować je jako trybunały ad hoc (MTKJ i MTKR) oraz stały trybunał międzynarodowy (MTK). Warto w tym miejscu zauważyć, iż wyróżnianie określonych typów trybunałów ze względu na kryterium czasu nie jest zabiegiem czysto abstrakcyjnym. Kryterium to ściśle koresponduje z pojęciem czasu w kontekście warunków kształtowania się współczesnego międzynarodowego sądownictwa karnego (gotowość państw do zaakceptowania konkretnych rozwiązań na kolejnych etapach jego rozwoju). Co więcej, trwałość lub przejściowy charakter trybunałów wiąże się ściśle z zakresem ich celów, a w konsekwencji - do pewnego stopnia - z zakresem ich jurysdykcji. Problem ten w aspekcie temporalnym omówiony zostanie w kolejnym punkcie.

\section{Jurysdykcja ratione temporis międzynarodowych trybunałów karnych}

Czas wydaje się nie tylko wpływać na rozwój idei międzynarodowego sądownictwa karnego oraz określać charakter współczesnych trybunałów karnych. W sposób bezpośredni wiąże się także z zakresem ich kompetencji. W tym świetle warto zwrócić uwagę na sposób ukształtowania zakresu jurysdykcji ratione temporis wybranych trybunałów. Warto też podkreślić związek tego zagadnienia z kwestiami omówionymi w punkcie poprzednim. Trudno bowiem nie dostrzec więzi między determinowanym czynnikiem czasu statusem konkretnego trybunału jako organu stałego bądź czasowego a zakresem jego właściwości czasowej.

Przypomnijmy, iż w odniesieniu do charakteru współczesnych trybunałów karnych kryterium czasu pozwoliło na przyporządkowanie MTKJ i MTKR do grupy 
organów niestałych. Zakres ich działalności w aspekcie temporalnym jest konsekwencją celu ich ustanowienia, jakim stało się osądzenie osób odpowiedzialnych za określone zbrodnie międzynarodowe popełnione w określonym miejscu i czasie. Jest to zasadnicze zadanie obu trybunałów, którego wykonanie powinno co do zasady skutkować zakończeniem ich działalności. Tym samym zakres jurysdykcji trybunałów ad hoc zawiera się w ustalonych ramach czasowych.

Ciekawym rozwiązaniem są regulacje dotyczące jurysdykcji czasowej MTKJ. Na mocy Statutu MTKJ ${ }^{30}$ jego jurysdykcja czasowa rozciaga się na czyny popełnione po pierwszym stycznia 1991 r. (art. 8 Statutu). W Statucie nie wskazano jednak w sposób równie precyzyjny daty końcowej. Wskazówką w tej materii pozostaje treść cytowanej już rezolucji 827 Rady Bezpieczeństwa NZ, w której stwierdzono, iż zakres jurysdykcji ratione temporis trybunału obejmuje okres od 1 stycznia 1991 r. do momentu, który wskaże sama Rada Bezpieczeństwa po przywróceniu pokoju w regionie ${ }^{31}$. W efekcie zakres czasowej jurysdykcji MTKJ zależy w dużej mierze od jednego z organów głównych ONZ. Rozwiązanie to może być oczywiście postrzegane jako próba zachowania pewnej dozy elastyczności w działalności trybunału, co może mieć znaczenie wobec skali naruszeń prawa międzynarodowego na terytorium byłej Jugosławii. Warto też przypomnieć sygnalizowane wyżej działania Rady Bezpieczeństwa wyrażające wolę zakończenia prac przez oba trybunały ad hoc (rezolucja 1503 Rady Bezpieczeństwa). Co jednak charakterystyczne, ustalenie daty wyznaczającej kres jurysdykcji czasowej MTKJ nie nastapiło wprost, a wydaje się być powiązane z faktycznym zamknięciem prac trybunału podyktowanym przywróceniem pokoju w regionie.

Zakres jurysdykcji czasowej MTKR został z kolei ujęty w sztywne ramy. Cytowana już rezolucja 955 Rady Bezpieczeństwa zakłada, iż trybunał powołany został w celu ścigania $i$ karania jednostek odpowiedzialnych za popełnienie określonych zbrodni na danym terytorium w okresie między 1 stycznia a 31 grudnia 1994 roku. Oznacza to, iż jurysdykcji trybunału podlegają jedynie zbrodnie, których dokonano we wskazanym przedziale czasowym. Potwierdza to Statut MTKR ${ }^{32}$, który w art. 7 stanowi, iż jurysdykcja czasowa trybunału rozciagga się na zbrodnie popełnione między 1 stycznia a 31 grudnia 1994 roku.

Rozwiązanie przyjęte w Statucie MTKR powoduje, iż z jednej strony zakres jurysdykcji ratione temporis trybunału został określony precyzyjnie, $\mathrm{z}$ drugiej jednak wskazany okres może wydawać się zbyt wąski, biorąc pod uwagę rozmiar naruszeń prawa międzynarodowego w konflikcie ruandyjskim. Zwracali na to uwage przed-

30 Zob.: Updated Statute of the International Criminal Tribunal for the Former Yugoslavia, źródło: http://www.icty. org/x/file/Legal\%20Library/Statute/statute_sept09_en.pdf [data weryfikacji: 24 kwietnia 2010 r.].

31 B. Krzan, op. cit., s. 211.

32 Zob.: Statute of the International Tribunal for Rwanda, źródło: http://69.94.11.53/ENGLISH/basicdocs/statute/2007.pdf [data weryfikacji: 24 kwietnia 2010 r.]. 
stawiciele rządu Ruandy. Ich zdaniem jurysdykcja czasowa MTKR powinna obejmować okres od października 1990 roku, gdyż zbrodnie podlegające kognicji trybunału stały się efektem długotrwałej polityki prowadzonej od początku lat dziewięćdziesiątych $^{33}$. W tym względzie, w odniesieniu do ludobójstwa, do Statutu MTKR włączono postanowienia umożliwiające pociagnięcie do odpowiedzialności także tych osób, które dopuściły się planowania tej zbrodni, bezpośredniego lub pośredniego podżegania do jej popełnienia bądź usiłowania i współudziału w jej popełnieniu (art. 2 ust. 3 lit. b-e Statutu). Na marginesie warto jednak zauważyć, iż szczegółowe rozwiązania przyjmowane w odniesieniu do struktury wewnętrznej MTKR czy możliwości orzekania kary śmierci wpłynęły na zmianę stanowiska Ruandy wobec trybunału ${ }^{34}$. Rząd Ruandy, który początkowo w sposób aktywny popierał utworzenie trybunału i jako niestały członek Rady Bezpieczeństwa współpracował w przygotowaniach Statutu, w decydującym momencie głosowania nad rezolucją był przeciwny jej przyjęciu ${ }^{35}$. Można więc uznać, iż aspekt czasu jako element kształtujący zakres jurysdykcji trybunałów karnych ad hoc w sposób bezpośredni determinuje stanowisko państw co do funkcjonowania tego rodzaju organów.

Jurysdykcja Międzynarodowego Trybunału Karnego, który jest trybunałem stałym, w aspekcie czasowym nie posiada charakteru uniwersalnego ${ }^{36}$. Zgodnie z art. 11 ust. 1 Statutu Rzymskiego jurysdykcja ratione temporis MTK obejmuje zbrodnie (wskazane w art. 5 ust. 1 Statutu) popełnione po wejściu Statutu w życie, co miało miejsce 1 lipca 2002 roku. Rozwiązanie to znajduje zastosowanie względem państw, które były stroną Statutu w momencie jego wejścia w życie. W wypadku państw, które przystapiły do Statutu później, jurysdykcja Trybunału rozciagga się na czyny popełnione po wejściu w życie Statutu w stosunku do takiego państwa. Warto także podkreślić, iż kształtowanie zakresu jurysdykcji czasowej w odniesieniu do poszczególnych państw może okazać się stosunkowo elastyczne. Zakres owej jurysdykcji zależy bowiem m.in. od decyzji państwa, w którym momencie do Statutu Rzymskiego przystapi. Co więcej, na mocy art. 124, państwo przystępujące do Statutu MTK może złożyć deklarację, iż przez kolejnych siedem lat (jednak nie dłużej) nie uznaje jurysdykcji MTK w odniesieniu do zbrodni wojennych (art. 8 statutu) popełnionych przez obywateli tego państwa bądź na jego terytorium ${ }^{37}$.

Wskazane wyżej główne regulacje Statutu, stanowiąc swego rodzaju ograniczenie jurysdykcji ratione temporis MTK, wychodzą naprzeciw zakazowi retroakcji,

\footnotetext{
33 B. Krzan, op. cit.

34 Por. J. Nowakowska-Małusecka, Odpowiedzialność karna jednostek za zbrodnie popełnione w byłej Jugosławii i Rwandzie, Katowice 2000, s. 50-51.

35 M. Zdanowicz, T. Dubowski, op. cit., s. 144.

36 M. Płachta, Międzynarodowy Trybunał Karny. T. I, Kraków 2004, s. 403.

37 Zgodnie $z$ art. 12 ust. 3 Statutu zakres jurysdykcji czasowej MTK może zostać również rozszerzony w stosunku do państw, które na mocy złożonej deklaracji uznaja jurysdykcję Trybunału w odniesieniu do zbrodni popełnionej przed datą wejścia w życie Statutu w stosunku do tego państwa.
} 
co przez przedstawicieli nauki oceniane jest pozytywnie ${ }^{38}$. Warto jednak zwrócić uwagę i na inne stanowisko. Może bowiem wydawać się, i podkreśla to M. Płachta, iż zbrodnie podlegające kognicji Trybunału od dawna posiadają status zbrodni międzynarodowych, a ich definicje obecne są w wielu aktach prawnych ${ }^{39}$. W takiej sytuacji rozszerzenie jurysdykcji MTK na zbrodnie popełnione przed wejściem w życie Statutu Rzymskiego miałoby szansę przyczynić się do realizacji idei ,powszechnej sprawiedliwości” bez naruszenia zasady nullum crimen sine lege ${ }^{40}$.

Ponieważ jednak o aktualnym kształcie MTK zadecydowała wspólna wola państw, warto w tym miejscu zwrócić uwagę na powiązanie czynnika czasu jako elementu określającego jurysdykcję MTK oraz jako czynnika rozwoju stałego sądownictwa międzynarodowego. Ujmując rzecz w uproszczeniu - bez względu na ocenę zjawiska - państwa na obecnym etapie rozwoju współpracy międzynarodowej były gotowe wyrazić zgodę na funkcjonowanie stałego międzynarodowego trybunału karnego w takiej, a nie innej formule, tj. z określonym w powyższy sposób zakresem jurysdykcji czasowej ${ }^{41}$. Można przypuszczać, iż stały trybunał międzynarodowy, jakim jest MTK, z inaczej (szerzej) określonym zakresem jurysdykcji ratione temporis w ogóle miałby nikłe szanse powstania.

Podsumowując, można stwierdzić, iż - paradoksalnie - ograniczenia jurysdykcji ratione temporis MTK oraz mechanizmy przesądzające o jej ,indywidualizacji” względem poszczególnych państw stały się czynnikiem umożliwiającym uzyskanie wystarczającej liczby ratyfikacji Statutu Rzymskiego i jego wejście w życie. W ten sposób doszło do realizacji idei stałego międzynarodowego sądownictwa karnego. W obecnym kształcie nie jest ono z pewnością tworem doskonałym. Jest jednak na pewno bardzo istotnym elementem rozwoju określonych idei prawa międzynarodowego posiadających niezwykle ważny aspekt praktyczny.

\section{Podsumowanie}

Aspekt czasu w rozwoju i funkcjonowaniu współczesnych międzynarodowych trybunałów karnych wydaje się posiadać niezwykle istotne znaczenie. Już w odniesieniu do rozwoju idei międzynarodowego sądownictwa karnego czynnik czasu okazuje się elementem kluczowym. Okazuje się bowiem, iż ustanowienie międzynarodowych organów sądowych w obecnej formie jest wynikiem dłuższego proce-

J. Izydorczyk, P. Wiliński, Międzynarodowy Trybunał Karny, International Criminal Court: powstanie, organizacja, jurysdykcja, akty prawne, Kraków 2004, s. 61.

M. Płachta, op. cit.

Ibidem

Warto dodać, iż już z racji na charakter i funkcje MTK jego efektywne funkcjonowanie w wymiarze praktycznym w dużej mierze zależy od woli państw do współpracy z Trybunałem. Stąd niezwykle ważne wydają się te inicjatywy i rozwiązania, które wychodząc naprzeciw oczekiwaniom państw, dają szansę na ich aktywne wsparcie dla działalności MTK. 
su, którego poszczególne etapy złożyły się na kształt nie tylko aktualnych rozwiązań instytucjonalnych, ale także bardzo istotnej dziedziny prawa, jaką jest zagadnienie odpowiedzialności międzynarodowej jednostek. Czas okazał się w tym wypadku czynnikiem umożliwiającym osiągnięcie zbiorowej zgody państw na realizację określonych idei i koncepcji, co w dziedzinie prawa międzynarodowego ma znaczenie fundamentalne.

Czas determinuje także charakter funkcjonujących obecnie międzynarodowych organów sądowniczych egzekwujących odpowiedzialność jednostki. Jednocześnie staje się on czymś więcej niż kryterium pozwalającym na schematyczne wyodrębnienie trybunałów stałych i czasowych. Czas, w zakresie, w jakim określa status poszczególnych trybunałów, łączy się bezpośrednio z uwarunkowaniami kształtowania się współczesnego sądownictwa międzynarodowego. Upraszczając - czas pozwolił państwom wyartykułować wspólną wolę utworzenia międzynarodowych trybunałów karnych, przy czym na obecnym etapie współpracy wola ta umożliwiła ustanowienie organów o określonym - kolejno - trwałym i przejściowym charakterze.

Wreszcie, element czasu w funkcjonowaniu międzynarodowych trybunałów karnych można oceniać z perspektywy zakresu ich jurysdykcji czasowej. W tym aspekcie czynnik czasu pozostaje w widocznym związku z charakterem poszczególnych trybunałów. Zakres jurysdykcji ratione temporis wydaje się bowiem bezpośrednio korespondować z czasowym bądź stałym charakterem omawianych trybunałów.

Czynnik czasu przenika zatem sferę funkcjonowania współczesnych trybunałów karnych w wielu aspektach - począwszy od rozwoju idei ustanowienia tego rodzaju organów, na ich jurysdykcji czasowej kończąc. We wszystkich tych obszarach elementy temporalne wydają się łączyć i w określony sposób przenikać. Oceniając działalność międzynarodowych trybunałów karnych z tej perspektywy, można jednocześnie dostrzec, w jak widoczny sposób problem ich rozwoju i funkcjonowania wpisuje się w specyfikę prawa międzynarodowego publicznego. 


\title{
THE TIME FACTOR IN THE FUNCTIONING OF INTERNATIONAL CRIMINAL TRIBUNALS - SELECTED ISSUES
}

\author{
SUMMARY
}

This article concerns the problem of time in the sphere of development and functioning of the contemporary international criminal courts and tribunals. The temporal aspects were analysed mostly in relation to the International Criminal tribunal for Yugoslavia, International Criminal Tribunal for Rwanda and International Criminal Court. Their genesis, character and ratione temporis jurisdiction have been described from the perspective of time factor.

In area of development of contemporary criminal tribunals a certain period of time seems to be the sine qua non condition for formulating states' common will concerning creation of international organs of such nature. It is especially important in relation to organs of permanent character (ICC). It is also worth noting that a factor of time lets describe international criminal courts and tribunals as permanent or temporary which seems to be linked with the scope of their temporal jurisdiction.

In this way the time factor seems to penetrate and influence the functioning of international criminal courts in all important areas of their genesis and their activity. 